\title{
9. Culture as a Key to Connections: Using culture to promote Australia's strategic relationship with Latin America
}

\author{
Ralph Newmark
}

\section{Introduction: A new lateral approach}

In the second decade of the 21 st century, globalisation and the digital revolution have made culture, in all its manifestations, a powerful vehicle for building global relationships and creating business. It was once said, in international relations, that culture follows commerce; however, this chapter sees culture as commerce itself and as a means of leading to greater commercial relations via knowledge transfer. It sees culture as a broad reciprocal phenomenon. While on the one hand, the flow of Australian cultural products into Latin America serves to enhance our profile in the region and also provides access for our artists to one of the largest markets in the world, on the other hand, the flow of Latin American culture into Australia has many significant benefits. Indeed, in terms of advancing Australia's strategic relationship with Latin America, the role of culture - especially popular music, dance and food-can be seen both as a means of developing a sadly lacking awareness and understanding of the region in this country and as a means of expanding existing - and developing new-commercial activities for Australians in Australia via the popularity and proliferation of Latin American culture. All these connections will generate economic benefits for Australia and Latin America.

However, a relationship cannot flourish in ignorance and apathy. This chapter seeks to make recommendations that will make the cultural context of AustraliaLatin American relations more productive. It is time to implement a lateral approach; to use a multi-faceted strategy in which culture can play a vital role. The chapter argues that while continuing calls for government to make Latin America a higher priority in terms of policy initiatives, the recent burgeoning popularity of Latin American culture in Australia should be harnessed and promoted as a means of increasing Australia's familiarity with and knowledge of Latin America and thus our connections to the region. This organic shift in consciousness and understanding will in turn help to create the conditions in which the potential of Latin America as a region for advancing Australian 
interests will permeate government, business, the education sector and the general community. Latin American culture can therefore be used in Australia to stimulate benefits for Australians, both domestically and in Latin America. In short, the link between culture and the overall strategic relationship with the region is that greater cognisance will lead to greater engagement on all levels.

Despite heroic efforts and achievements in the past by people such as Justin Macdonnell and organisations including the Australia Latin American Foundation (ALAF), a fragmented, piecemeal approach has been the hallmark of culture's role in Australia's relationship with Latin America. Accomplishments are manifest, but relatively modest: Australia needs to use the extraordinary domestic explosion of interest in Latin American culture to its best advantage.

Advancing strategic links must be seen as a multi-pronged integrated strategy, with each sector considered in this book doing what it does best. The role of culture is primarily to create appreciation and understanding, but it can also be profitable in itself. From a macro perspective, the promotion of Latin American culture in Australia as part of a total strategy makes sense. Linked together with all the other components analysed within this volume - such as trade, investment, and the education sector - we can promote and advance a reciprocal strategic relationship. If culture can put Latin America on the radar in Australia and vice versa, then all sorts of mutual benefits will flow. Some people may see this use of culture as somewhat nebulous, but it could be argued that this is the key role of culture in any broad strategic plan: its ability to create a knowledge platform from which to develop trade relationships.

This lateral approach also comprises boundless economic opportunities for people in Australia to gain from the popularity of domestic Latin American culture. In purely economic terms, Latin American culture in this country is becoming an important area of commercial activity for Australian business, via sales of recorded and now online music, as well through the proliferation of entertainment venues, dance schools and concert tours. In addition, there has been an explosion of interest in the region's cuisine.

Each part of this chapter will provide an assessment of the present situation in historical perspective, identify the major stakeholders, and also suggest future strategies in order to enhance our relationship with Latin America using culture as one key to connections and commerce. Part 1 examines Australia's cultural presence in Latin America, while Part 2 analyses Latin American culture in Australia. Finally a number of general recommendations are set out for future directions. 


\section{Part 1: Australia's cultural presence in Latin America}

\section{The present situation}

Latin America and Australia have traditionally shared a relationship characterised by ignorance and apathy. This is surprising given that both share many historical characteristics, such as conquest and settlement by Europeans. Perhaps the fact that for many years we have been competitors in terms of export commodities has inhibited the development of trade linkages. Nevertheless, in recent times economic connections have steadily increased through investment, trade educational exports, and cultural exchanges.

Beginning in the 1980s, culture became a factor in this relationship through the pioneering work of Justin Macdonnell, who undertook a number of studies for the Australia Council on the development of a cultural tours program for Australian artists. In his report of May 1991, Macdonnell argued that 'a potential new market clearly existed in Latin America for shrewdly chosen Australian [cultural] product'. ${ }^{1}$

In 1992, Macdonnell's submission to the Senate hearing on Australian-Latin American relations recommended: 'There needs to be a recognition that without a change in the present low priority in our cultural relationship with at least the five 'priority' nations of Mexico, Argentina, Venezuela, Chile and Brazil, Australia runs the risk of failing to build bridges for the future' ${ }^{2}$

Soon after, a group of Australians and Latin Americans resident in Australia led by Mario Estrella and Macdonnell established the Australia Latin America Foundation (ALAF) in order 'to promote better cultural relations between Australia and the countries of Latin America'. ${ }^{3}$ Starting in the early 1990s, the ALAF successfully implemented many cultural exchanges with Latin America. The foundation's website clearly details its record of achievements, commencing in 1992 when the ALAF was launched:

for the five hundredth anniversary of the first encounter between the peoples of Europe and the peoples of America (the Columbus Quincentenary). This was marked by a major Australian presence in the Caracas International Theatre Festival and the IberoAmerican Theatre

\footnotetext{
1 Senate Standing Committee on Foreign Affairs, Australia and Latin America: 'The Report of the Senate Standing Committee on Foreign Affairs, Defence and Trade, Companion Volume 6', 1992, p. 2063.

2 Ibid, p. 2012.

3 Australia Latin America Foundation, 'Columbus Quincentenary', http://alafoundation.com/, accessed 20 May 2013.
} 
Festival of Bogotá in March of that year. This included Circus Oz, the Sydney Dance Company, Theatre of Image, Stretch Mk 1, playwrights Richard Whaley and Alma de Groen, arts critics Leonard Radic and Martin Portus. That, in turn, was complemented by a major Latin American presence at the Melbourne International Arts Festival in October that year, involving the National Ballet of Cuba, Jaime Torres y su Gente, Daniel Binnelli Quintet, and NucleoDanza. This was the first time that such a focus on the other region's culture had occurred in either place. All were curated by the Foundation. ${ }^{4}$

Since then the ALAF has worked with a range of public and private organisations as well as individuals 'to promote and manage Australian artists and ensembles to tour on a select and strategic basis in Latin America', and 'has worked with or co-presented Latin American artists with the Adelaide, Melbourne and Sydney Festivals', and lately at the 2012 Brisbane Festival. ${ }^{5}$

Recent developments and current projects involving the ALAF include: liaising with Latin American embassies in Canberra; key foundation associate Frank Madrid's appearance at the Latin Alternative Music Conference in New York; a Music Road Show in Argentina; arranging in Argentina, Colombia and Mexico for co-productions with Australian performing arts institutions and artists over the next three years; and organising residencies for Australian artists in Mexico City and Guadalajara. One can only applaud the efforts of the ALAF: its work provides a vehicle for promoting the presence of Australian artists in Latin America and this is an important contribution.

On the level of government involvement in cultural policy, a decade after the Senate report on Latin America, COALAR commissioned Justin Macdonnell from the ALAF in 2002 to write a report that 'considered how to improve coordination of Australian cultural activities in the region'. ${ }^{6}$ Significantly, the 2002 Macdonnell report entitled Australia's Cultural Presence in Latin America called for cultural policy that employed 'a whole of government approach to maximise both input and outcome' and went on to emphasise that:

partnerships within government and between tiers of government will be crucial; that partnerships with those private interests in the cultural and business sectors which have a stake in region, whether based in Australia or in Latin America, should be reinforced where they exist and promoted where they do not. ${ }^{7}$

5 Ibid; see also 'ALAF Projects', http://alafoundation.com/projects.htm, accessed 20 May 2013.

6 Justin Macdonnell, Australia's Cultural Presence in Latin America: Programs and Prospects, Prepared for COALAR, by ALAF Limited, February 2003, p. 3.

7 Ibid. 
In April 2009, The Australia Council launched a new market development strategy in Latin America concentrating on Brazil and Mexico:

[The Australian Export Strategy for Latin America]...promotes and profiles emerging and established Australian contemporary artists and companies from the small to medium sector in South America, with a specific focus on Mexico and Brazil. Mexico and Brazil are key cultural centres attracting buyers, artists and tastemakers throughout the world. Both have considerable cultural history and significant contemporary practice as well as sizeable Indigenous communities, making them a good fit for contemporary Australian work. ${ }^{8}$

The identification of Indigenous connections here is of great importance. Both Australia and Latin America have traditionally been guilty of tragically hypocritical approaches to their original inhabitants. On the one hand, there are mutual histories of dispossession, cultural destruction and racism. Yet when it comes to the construction and marketing of identifiable national symbols and cultural products by some commercial organisations, the use of stereotyped images of Indigenous peoples and indeed animals has been clearly exploitative. Let us hope that all future collaborations will be directed and conducted by the Indigenous peoples themselves on their terms.

Another opportunity for Australia to make an impact in Latin America is at the Sixth World Summit on Arts and Culture in January 2014, conducted by the Chilean National Council for Culture and the Arts. Australia held the Fifth World Summit, co-hosted by the Australia Council for the Arts and the International Federation of Arts Councils and Culture Agencies (IFACCA), in Melbourne during October 2011 and it attracted 501 delegates from 72 countries. According to the Australia Council:

The theme of the Summit, Creative Intersections, was explored by over 80 speakers who provoked wide-ranging debate around the role of innovative government policy in facilitating intersections between the arts and other sectors for the benefit of the broader community, including health and well-being, education, environmental action, business, international aid, social inclusion and digital technologies. ${ }^{9}$

This Australian-Latin American 'Pacific Rim' continuity between the two Summits provides an ideal opportunity to enhance dialogue on cultural collaboration.

8 Australia Council, 'Targeted strategies for key international markets', Australia Council Media Release, 8 April 2009.

9 Australia Council, 'Let the Proceedings Begin: The Fifth World Summit on Arts and Culture Kicks Off Today in Melbourne', http://www.australiacouncil.gov.au/news/items/news, accessed 20 May 2013. 
In 2010, the Victorian state government published a vision statement for the enhancement of that state's relationship with Latin America. The 29-page document included trade, investment and culture and acknowledged that culture through music, the visual arts and theatrical projects had a significant role to play in establishing connections. According to the report, 'a number of projects are being pursued by Victorian arts and cultural organisations in 2010-2013:

- Museum Victoria pursued the opportunity to host a touring exhibition from Mexico on Aztec culture in 2010-11.

- Latin America featured in a new forward plan around international touring being developed by the Melbourne Symphony Orchestra. The Melbourne Symphony Orchestra actively pursued Latin American touring opportunities including a visit to Chile.

- The Australian Centre for Contemporary Art extended its international tour of a prestigious Patricia Piccinini sculpture exhibition (Singapore, India and Japan) including Mexico in 2010-11.

- Multicultural Arts Victoria was invited by the Chilean Bicentenary Commission to send a culturally diverse music ensemble, Melbourne Ska, to perform in three locations in northern Chile in 2010. ${ }^{\prime 10}$

These Victorian initiatives are excellent examples of what can be achieved at the state level and it can only be hoped that future state governments continue to implement this agenda.

Nevertheless, since the 1990s the most notable example of an Australian cultural presence in Latin America has been at Colombia's Festival Iberoamericano de Teatro de Bogotá. This prestigious festival has drawn Australian performers since 1992, and the list of participants is impressive. According to Colombian educator Jorge Leiva, while Australia's presence is much appreciated, a better identification of Australian acts, especially in the realm of street theatre, would serve to create a wider knowledge of Australia's contribution to the festival. ${ }^{11}$

Individual artists with a love of Latin American culture have also played a role in promoting Australia in Latin America. An important example is Melbourne jazz guitarist Doug de Vries, who along with singer Diana Clarke are Australia's foremost exponents of Brazilian music. De Vries and Clarke have visited Brazil many times and De Vries comments that:

10 Department of Innovation, Industry and Regional Development (DIIRD), Victoria, Latin America and Victoria: A vision for growing trade, investment and cultural links, Melbourne, State Government of Victoria, 2010, p. 15.

11 Newmark, Interview with Jorge Leiva, 8 October 2010. 
Many Brazilians I've encountered in Rio, São Paulo, Salvador, Recife and other cities have a fascination for Australia and are quick to point out the similarities, such as our beaches, rainforests, deserts and climate. They also comment on the relative youthfulness of our colonial histories and how we share a relaxed lifestyle... they are often surprised and delighted when they learn of my knowledge and expertise in samba, choro and bossa nova, and are enthusiastic about how this musical dialogue has developed. ${ }^{12}$

At the micro level, these artistic encounters are encouraging and very helpful.

Mention must also be made here of a number of Australian rock bands that have great popularity in Latin America. These include AC/DC, INXS and, in the past, Men at Work, as well as bands that fall within the surfie sub-culture. Although internationally fans are aware that certain groups happen to be Australian, the problem is that our contemporary musical culture is derived from Anglo and US genres, so, in comparison to Latin American music, most of our music lacks a clear identity overseas.

Finally, there is sport. While both Australia and Latin America share a passion for sport, the main spectator sports only overlap to a limited extent. Australia's presence at the last two soccer World Cup finals in 2006 and 2010 certainly created interest in Latin America, as did the Socceroos' epic but failed attempts to qualify in 1994 against Argentina, and in 2002 against Uruguay. As Brazil is about to host the two biggest sporting events in the world-World Cup 2014 and the Olympic Games 2016-it is hoped that Australia's presence at both events will create an impact.

These two major events have also created linkages via sport on other levels. Australia's very successful staging of the Olympic games in 2000 has led to a demand for our expertise in the areas of sports administration and sports facilities. A considerable number of Australian companies and sports organisations have been active in Brazil in the lead-up to the momentous sporting occasions scheduled for the Brazilians in 2014 and $2016 .^{13}$

Nevertheless, our love of cricket and the four-way split in football codes means that niche sports are the key to future connections. Surfing and tennis stand out as vehicles for promoting Australia's presence in Latin America. Brazil and

12 Newmark, Interview with Doug de Vries, 18 January 2011.

13 See ABCC-Australia Brazil Chamber of Commerce, 'Feed Back on FIFA World Cup 2014 and Rio Olympics 2016 Business Mission', http://www.australiabrazil.com.au/index.php?option=com content\&task=view\&id=274, accessed 26 May 2013; Austrade, '2014 Brazil FIFA World Cup and 2016 Rio Olympic Games - For Australian exporters', http://www.austrade.gov.au/Export/Export-Markets/ Countries/Brazil/Industries/2014-Brazil-FIFA-World-Cup-and-2016-Rio-Olympic-Games, accessed 26 May 2013; ICN-Industry Capability Network, 'Victorian Industry prepare for Rio Olympic Games following success in London', http://www.icnvic.org.au, accessed 27 May 2013. 
Peru are great surfing nations and our champions are important icons in those countries. Also the Australian Open, as one of the international Grand Slams, attracts many great Latin American players, especially from Argentina and Chile.

\section{Future strategies}

In order to promote the cultural presence of Australia in Latin America, two further strategies in addition to those already discussed ought to be implemented.

First, Australia should take advantage of the historical links between our continents to promote our profile in the region. Many important political, artistic and scientific figures visited and worked in both areas during the 18th and 19th centuries and have left wonderful historical legacies. People such as Charles Darwin, Charles Joseph La Trobe - who spent time in Mexico during 1834 - and Australia's third Prime Minister, Chris Watson - who was born in Valparaiso, Chile - come to mind. Indeed, Watson was the world's first elected head of a national government to come from the labour movement, in this case the ALP. Brazil's 2010 'Connections' exposition held in Canberra, Sydney and Melbourne was a good example of the use of history to forge bonds and build profiles. This exhibition highlighted the geological, biological, and artistic links between the two nations. Another fruitful project using history could be developed with Paraguay that considers William Lane's utopian experiment of the 1890s. Cultural attachés at Australian embassies in Latin America should be encouraged to explore these historical connections and develop exhibitions in consultation with historians.

As a second additional strategy, there should be a strict policy of clearly identifying Australian performers in Latin America. This is especially crucial in the genres of street theatre and outdoor concerts. As most Australian performing artists address universal themes and rightly eschew clichéd cultural stereotypes, accompanying promotional content would help to ensure that mass audiences linked these performances to Australia.

Each of the initiatives discussed in this section has served to promote the presence of quality Australian performers in Latin America and are of great merit. They should not only continue, but be expanded. They serve to raise Australia's profile as a diverse, sophisticated, and developed nation in the eyes of Latin American audiences. While most of them target niche demographics, taken together they can reach a range of people from influential elites, in the case of concert hall performances, to sections of the general public during street theatre. The flow of Australian cultural products into Latin America serves to enhance our profile in the region and also provides access for our artists to one 
of the largest markets in the world. Nevertheless, as we shall see in Part 2, it may well be on the home front that culture can make the most dynamic contribution to this strategic relationship.

\section{Part 2: Latin American culture in Australia}

The popularity of Latin American popular culture in Australia has undergone steady growth since the 1980s and is presently experiencing a significant boom. Prior to the 1980s, interest in Latin American culture was generally confined to a small group of academics and activists. But from the late 1970s, inner-suburban gentrification was linked to the rise of a young, educated and sophisticated urban demographic. This group developed a distinct appetite for cultural exotica and as a consequence the market expanded for 'Third World' food, music and culture in general.

In terms of food, this market was catered for by the wave of immigration that flowed into Australia after the abolition of the White Australia Policy. However, for other forms of culture such as music and dance, the market for exotica took another course. As immigration from Latin America to Australia had not been similar to the levels experienced from Asia, our experience of the region has been characterised by a distinct lack of knowledge. Paradoxically, this situation has served to fuel the perception of the exotic for anything deriving from Latin America. When added to the inherent sensory and sensual appeal of Latin America's hybrid culture, consisting of Indigenous, Iberian, and African elements, the exotic appeal of the region's culture has had particular resonance with the predominantly inner-suburban, educated and middle-class audience. In this period - the 1980s to the mid-1990s - genres such as salsa and tango rapidly gained popularity. In terms of immigration, one must add that while the numbers of Latin Americans coming to Australia has been relatively small, migrants from Chile, El Salvador, Argentina, Uruguay and more recently Colombia and Brazil have played a key role in forming musical groups that service the public's appetite for Latin music.

Since the mid-1990s another factor has served to expand the appeal of Latin American culture in Australia: the explosion of a visible and assertive Latino culture in the United States. The globalised US-driven music industry now serves to spread interest in Latin music and this has captured a new Australian audience, both younger and more diverse, that regularly listens and dances to contemporary genres of Latin American music. These range from modern 
techno-salsa and merengue to Latin hip-hop and reggaeton. The music emanates from countries such as Colombia, Peru, Argentina, Mexico and Brazil, and not just the United States. There is also a strong demand for music from Cuba. ${ }^{14}$

\section{The present situation}

\section{Recorded music}

In recent years the recorded music industry has been undergoing a revolution in delivery formats. Digital media such as MP3/MP4 formats and, increasingly, online streaming are rapidly replacing physical formats such as CDs, and 'while revenue levels are adjusting to the change due to cheaper prices and piracy, the market for music will continue to grow in the long term'. ${ }^{15}$ According to the Australian Bureau of Statistics (ABS) figures, the wholesale value of recorded music sales in Australia for the year ending 31 December 2012 totalled \$398.1 million. These figures come during a period of dramatic transition in delivery systems. In 2007 digital sales accounted for \$39.9 million in sales value. By 2012 this number had risen to $\$ 184.3$ million. ${ }^{16}$

In global terms, during 2009 'Digital music sales, which include song downloads, mobile music, online subscriptions and streaming via advertising-supported services [such as YouTube] grew by 24 per cent globally to \$US3.78 billion.' ${ }^{17}$ By 2012 that figure reached US $\$ 5.6$ billion. Leading providers of digital music include iTunes, Amazon.com, and bigpondmusic.com, while delivery systems include mobile phones, iPods, digital music systems, and of course all forms of computers. In general terms, whether physical or online, music is big business.

Based on the figures for 2012, in Australia retail sales of World Music are estimated at around five per cent of total sales, equivalent to around $\$ 20 \mathrm{~m}$ in value, of which approximately 70 per cent, or more than $\$ 14 \mathrm{~m}$ in value, is Latin American music. In short, music from the region is overwhelmingly the most popular form of World Music and importantly, while beginning from a low base compared to other genres, the potential for growth is considerable. ${ }^{18}$ While one could argue that the majority of profit from the sale of digital music in Australia does not accumulate here, in terms of the range and accessibility of Latin music now available in Australia, the digital revolution has been a boon for the growth of our interest in Latin American music.

14 For an analysis of the history and appeal of Latin American music in Melbourne see Neil Orchard, 'Oz Salsa: A True Multicultural Dip?', unpublished Honours Thesis, La Trobe University History/Anthropology Programs, 2008.

15 Australian Recording Industry Association (ARIA), Annual Report 2008.

16 Australian Recording Industry Association (ARIA), Annual Report 2012.

17 ABC News, 22 April 2009.

18 Interview with JB HiFi sales staff, Camberwell, Victoria Music Department, May 2013. 


\section{Concert tours}

Linked to the growing popularity of Latin American culture is a proliferation of concert tours undertaken by individual artists, bands, and increasingly by showcase productions that present aspects of musical culture from the region. Tours by Latin American musical groups go back to the 1970s, when Chilean Nueva Canción ensembles including Inti-Illimani and Quilapayún drew a predominantly politically motivated audience. By the 1990s the worldwide phenomenon of the Buena Vista Social Club led to a succession of popular tours that showcased Cuban music and in many ways served as a massive stimulus to the popularity of Latin American music in Australia. Further, between 2009 and 2013 numerous shows dealing with Brazilian and Cuban musical culture toured Australia.

\section{Venues: Live music and clubs}

In Melbourne and Sydney and other capital cities there is now an abundance of venues that present Latin American music every week. The audiences for these clubs are drawn from a demographic range, but the vast majority are people from non-Latin American backgrounds, confirming the argument that Latin music clearly moves beyond its ethnic base. Local musicians, many of who are migrants from Latin America, service Australia's music and dance venues, but, increasingly, recorded Latin music provided by DJs is used in clubs. While this is bad news for live music entertainers in the capital cities, it is at least a relatively cheap means of spreading the experience and consumption of Latin American culture.

\section{Festivals}

There is a significant number of Latin American cultural community festivals held each year in Australia. While the various multicultural communities from Latin America and Iberia usually organise these events, the attendance at the major festivals derives overwhelmingly from the general public. Once again the inherent exotica and sensuality of Latin American culture serves to draw a broad range of patrons to these festivals. At the events most of the traders are involved in domestic commercial activities that relate to Latin American culture, ranging from music sellers to restaurant owners, and have stalls showcasing their products. In Melbourne, the annual Hispanic-Latin American Festival held in Johnson St, Fitzroy has become a major attraction, while the Chilean Festival held each year at Sandown Park draws significant crowds. The South American Festival at the Bondi Pavilion features Sydney's large Brazilian community and both the Darling Harbour Fiesta - Latin Dance and Music Festival and the Sydney Salsa Congress are also indicative of the Latin American cultural boom in Australia.

The other type of festival attracting the general public to Latin American culture is the state arts festival, of which there are several examples. While 
presenting a diversity of artistic activities, these have tended in recent years to include performance groups from Latin America. These appearances often link with national concert tours already mentioned. In 2012 the Melbourne International Arts Festival, the Sydney Festival, the Adelaide Festival of the Arts, the Brisbane Festival, and the Perth International Arts Festival all featured artists from Latin America.

\section{Online information services}

Perhaps the most important means of disseminating information regarding Latin American culture in Australia is the emergence, in Melbourne and Sydney, of websites that provide extensive news of events and especially music and dance venues and schools. These online services have become the main conduits for publicising events and are favoured by contemporary aficionados. The main websites are in Melbourne, Latin Lover and Latinhub; and in Sydney, Viva Magazine and spanishaustralia. ${ }^{19}$

\section{Dance}

One of the most popular manifestations of Latin American culture in Australia has been dance. Thousands of people regularly frequent dance schools to learn various forms of Latin dancing such as tango and salsa as well as the Brazilian martial arts/dance form capoeira.

An additional dimension to dance has been the emergence in Australia of Latin American-related exercise classes. The Zumba dance fitness phenomenon was created by dancer and choreographer Alberto ('Beto') Pérez in Colombia during the 1990s, but is now based in Florida. It provides a frenetic workout to the rhythms of predominantly Latin American-based musical forms such as cumbia, salsa, merengue, mambo, cha-cha, reggaeton, samba and tango. In Australia there appear to be over 1,000 different classes available to people who are drawn to this potent mix of sensual Latin American culture and the developed world's obsession with weight loss and fitness. ${ }^{20}$

\section{Food and drink}

The engagement of Australians with Latin American cuisine is certainly one area of cultural appreciation that should be part of a greater cultural knowledge strategy. Australia has for some time embraced the Cal-Tex-Mex Americanised versions of Mexican food, but the magnificent complexity and diversity of Mexico's cuisine has had little exposure in this country. One recent development with potential for

19 See Latin Lover, http://www.latinlover.com.au/, accessed 27 May 2013; Latinhub, http://www.latinhub. com.au/latin-culture, accessed 27 May 2013; Spanishaustralia, http://www.spanishaustralia.org/arts, accessed 27 May 2013; Viva Magazine http://www.vivamagazine.com.au/, accessed 27 May 2013.

20 See Zumba Fitness, http://search.zumba.com/classes/internationalresults. 
disseminating a broader appreciation of Latin American food is Melbourne food expert Stephanie Alexander's keen interest in the region. On a trip to Mexico she linked her home town with a dish that no Australian diner would have enjoyed at a local Mexican chain restaurant; she recounted asking a market vendor in Mexico 'how to prepare the nopales - after all, I walk past stands of prickly pear along the banks of the Yarra River and might give it a go sometime' ${ }^{21}$

The present trajectory of Mexican cuisine in Australia has been polarised. At the top end of the market, the present fad for up-market 'Modern-Mex' cuisine has led to the proliferation of very popular and expensive restaurants that serve creative versions of Mexican classics. At the other end of the spectrum, the socalled 'Taco Truck' phenomenon has brought late-night mobile Mexican food to the streets with locations announced through social media.

The cuisine of Brazil is yet another genre which is underdeveloped in Australia. In this country Brazilian restaurants have chosen to concentrate predominantly on the southern Brazilian tradition of Churrascarias. The extraordinary food of Bahia, which includes an array of African flavours, would be an exciting addition to the culinary landscape of Australia. SBS should be encouraged to produce a television series that concentrates on Latin American food in all its diversity.

As for beverages, Mexican beer and spirits are well established here and probably increase familiarity with Latin America-hopefully beyond stereotypical images. One area that could be promoted is the world of Cuban cocktails based on rum produced in Cuba. The Mojito, Daiquiri, and Cuba Libre are well suited to the Australian climate and are becoming very popular.

\section{Film}

Film is yet another cultural medium that can be used for promoting familiarity and knowledge of Latin America. In Melbourne, for over a decade, the Filmoteca group has led the way in bringing Latin American films to the Australian public. Also there are a number of annual film festivals that concentrate on films from the region. Indeed, there has been a virtual explosion in the popularity of Latin American cinema in Australia, with the Melbourne and Sydney Latin American Film Festivals as outstanding examples and the La Mirada Film Festival also providing 'A showcase of contemporary and timeless film classics from Spain and Latin America'. ${ }^{22}$

21 Stephanie Alexander, 'Colours you can taste', The Age (Epicure), 13 October 2009.

22 See La Mirada Film Festival 2012, http://www.lamirada.org.au/. 


\section{Education}

Education is an invisible Australian export: the country provides educational services to Latin America by attracting fee-paying students from the region. However, the teaching of university-level subjects in Australia involving Latin American history, politics and culture also has a role to play in enhancing our nation's knowledge of the region. In particular, Victoria's La Trobe University has pioneered the use of popular culture as a means of teaching Latin American history. Indeed, in 1976 La Trobe's Institute of Latin American Studies (ILAS) became Australia's first academic centre dedicated to the study of Latin America, and since then has been involved in teaching and conducting research on the region. Over the past 17 years, ILAS's summer and winter Intensive Schools have specialised in using popular culture as a vehicle to bring knowledge of Latin America to both students and the general public in Victoria. ${ }^{23}$

Over the years universities in other states began to offer subjects that dealt with the region, many of which had some cultural components, especially University of New South Wales and Flinders University of South Australia. In recent times, University of Technology, Sydney, University of Queensland, Sydney University, University of Western Sydney, The Australian National University, Melbourne University and Monash University have all begun to focus on Iberian and Latin American areas of study.

The founding of the Association of Iberian and Latin American Studies of Australasia (AILASA) in 1993 was an important milestone, as its agenda was to:

- promote research into and the teaching of Iberian and Latin American Studies in Australasia;

- promote the professional development of its members;

- promote public recognition of and interest in the Iberian Peninsula and Latin America;

- stimulate and encourage interchange between Australasia and the Iberian Peninsula and Latin America; and

- coordinate and rationalise available resources among member institutions through the interchange of students, teachers and resources. ${ }^{24}$

But overall, while there has been a very welcome increase in the proliferation of subjects dealing with language and literature, there needs to be increased support for teaching and research in disciplines such as Latin American History, Politics, Cultural Studies, Sociology and Economics.

23 The Institute of Latin American Studies (ILAS), La Trobe University, Faculty of Humanities and Social Sciences, School Humanities: Latin American Studies Program: see http://www.latrobe.edu.au/ilas/.

24 Association of Iberian and Latin American Studies of Australasia (AILASA), See: http://www.ailasa.org/. 
A promising initiative in the area of educational exchange has been the $M i$ amigo internacional (My international friend) project run by Melbourne-based Colombian educator Jorge Leiva's peopleartpeople organisation. This program seeks to provide 'A creative journey in which young people in Australia explore and exchange with a friend in Colombia their sense of identity, family and world through visual arts shared through the web' ${ }^{25}$ This pilot project linked year nine and year ten art students from the Margaret Lyttle Memorial School in Preshil, Australia, with Colombian students as part of the Art and Youth for Peace Social Project from the Academia de Artes Guerrero. The program covered 20 one-hundred-minute sessions and the students from each country created:

artworks that addressed topics such as: Me, My family and home, My school, You and me, Our world, My country, My city, etc. Images of the artworks were exchanged via a website and discussed in class. According to Leiva, the pilot produced impressive results. ${ }^{26}$

Projects such as this are invaluable in creating awareness in the next generation of the world beyond Australia: the innovative use of contemporary technology via the internet is to be applauded. In the context of Australia and Latin America we see here the use of a cultural medium as a means of enhancing connections, recognition and understanding.

\section{Future strategies}

In order to consolidate the presence of Latin American culture in Australia a number of strategies should be implemented. The recent explosion in the popularity of Latin American culture should be encouraged, harnessed and used as a means of increasing Australia's consciousness and knowledge of the region by promoting and funding public festivals and events involving Latin American music, dance and food. Furthermore, support should be provided through COALAR for increasing the development of educational resources in Australia aimed at teaching courses that deal with Latin American culture and Latin American Studies in general, as well as the Spanish and Portuguese languages. In addition, the implementation of programs such as Mi amigo internacional (My international friend) should be encouraged in order to benefit a wide range of schools. Bringing cultural exchange to the level of secondary education will create a platform of knowledge that will produce benefits for Australia and Latin America.

25 See http://www.peopleartpeople.com/education.html.

26 Jorge Leiva, 'Mi amigo internacional [My international friend] project', http://www.peopleartpeople. com/education.html. 


\section{Summary of recommendations and future directions}

Cultural policy should play a role in a multi-pronged integrated strategy designed to advance Australia's strategic relationship with Latin America, both here and in Latin America. This cohesive approach should involve all the sectors covered in this volume and could well be coordinated by an organisation such as COALAR. The particular role of cultural relations is both educational and commercial and must harness the recent explosion of popularity of Latin American culture in Australia. The crucial linkage is culture's power as both a means of increasing Australia's connection to the region and providing profitable goods and services within the domestic market, especially those markets involving Latin American music, dance and food.

In terms of Australia's cultural presence in Latin America, the guidelines outlined in Justin Macdonnell's, Australia's Cultural Presence in Latin America: Programs and Prospects, should continue to be followed, in conjunction with the Australia Council (OZARTS) and the Australia Latin America Foundation (ALAF). In addition, during performances in Latin America, Australian artists should be more clearly identified, and in both Australia and Latin America exhibitions should be mounted which emphasise the historical links between the regions.

Support should be given through COALAR for increasing the development of educational resources in Australia aimed at teaching courses that deal with Latin American culture and languages as well as Latin American Studies in general. Ultimately, in terms of advancing Australia's strategic relationship with Latin America, the role of culture - especially popular music, dance and food - should be seen as a powerful means of developing awareness and understanding of the Latin American region in this country; more crucially, it should be recognised as a means of expanding existing, and developing new commercial activities for Australians. We must harness the boom. In the end, all of these connections will generate economic benefits for both Australia and Latin America. 


\section{References}

\section{Published and unpublished sources}

ABCC - Australia Brazil Chamber of Commerce, 'Feed Back on FIFA World Cup 2014 and Rio Olympics 2016 Business Mission', http://www.australiabrazil. com.au/index.php?option $=$ com_content\&task=view\&id $=274$, accessed 26 May 2013.

Alexander, Stephanie, 'Colours you can taste', The Age(Epicure), 13 October 2009.

Austrade, '2014 Brazil FIFA World Cup and 2016 Rio Olympic Games-For Australian exporters', http://www.austrade.gov.au/Export/Export-Markets/ Countries/Brazil/Industries/2014-Brazil-FIFA-World-Cup-and-2016-RioOlympic-Games, accessed 26 May 2013.

Australia Council, 'Targeted strategies for key international markets', Australia Council Media Release, 8 April 2009 and http://www.australiacouncil.gov. au/news/items/news, accessed 20 May 2013.

, 'Let the Proceedings Begin: The 5th World Summit on Arts and Culture Kicks Off Today in Melbourne', http:/www.australiacouncil.gov.au/ news/items/2011/let_the_proceedings_begin_the_5th_world_summit_on_ arts_and_culture_kicks_off_today_in_melbourne, accessed 20 May 2013.

Australian Recording Industry Association (ARIA) Report 2008; http://www. aria.com.au/pages/statistics.htm, accessed 25 July 2011.

,'WholesaleFigures', http://www.aria.com.au/documents/2012wholesalefigures. pdf, accessed 15 May 2013.

Bendrups, Dan, 'Melbourne's Latin American Music Scene', Perfect Beat, vol. 5, no. 2, 2001, pp. 19-29. Department of Foreign Affairs and Trade, Australia, Committee on Australia-Latin America Relations (COALAR), Annual Reports, 2002-2003 to 2008-2009.

Department of Innovation, Industry and Regional Development (DIIRD), Victoria, Latin America and Victoria: A vision for growing trade, investment and cultural links, Melbourne, State Government of Victoria, 2010.

ICN-Industry Capability Network, 'Victorian Industry prepare for Rio Olympic Games following success in London', http://www.icnvic.org.au, accessed 27 May 2013. 
Leiva, Jorge, 'International Creative Partnerships for Cultural Education and Promotion: The Case Between Colombia and Australia', unpublished Master of Teaching thesis, Melbourne Graduate School of Education, The University of Melbourne, 2010, p. 64.

Leiva, Jorge, 'Mi amigo internacional (My international friend) project', http:// www.peopleartpeople. com/education.html, accessed 27 May 2013.

Macdonnell, Justin, Australia's Cultural Presence in Latin America: Programs and Prospects, Prepared for COALAR, by ALAF Limited, February 2003.

Orchard, Neil, 'Oz Salsa: A True Multicultural Dip?', unpublished Honours Thesis, La Trobe University History/Anthropology Programs, 2008.

Senate Standing Committee on Foreign Affairs, Australia and Latin America, 'The Report of the Senate Standing Committee on Foreign Affairs, Defence and Trade, 1992', and companion volumes 1-6.

\section{Interviews and correspondence:}

Correspondence with ABC, January-April 2010.

Correspondence with SBS, January-May 2010.

Interview with JB HiFi Music Department, Camberwell, Victoria, 27 January 2013.

Interview with Jorge Leiva, 8 October 2010.

Interview with Doug de Vries, 18 January 2011.

Interview with Justin Macdonnell, 10 June 2010.

Interview with Max Vella, owner: Night Cat Night Club, 17 October 2010.

\section{Key websites:}

Australian Latin America Foundation, http://alafoundation.com/

AILASA-Association of Iberian and Latin American Studies of Australasia, http://www.ailasa.org/

ANCLAS-Australian National Centre for Latin American Studies, http:// anclas.anu.edu.au/

Filmateca, http://www.melbournefilmoteca.org/ 
ILAS - Institute of Latin American Studies at La Trobe University, http://www. latrobe.edu.au/ilas/

La Mirada Film Festival 2012, http://www.lamirada.org.au/

Latin Lover, http://www.latinlover.com.au/

Latinhub, http://www.latinhub.com.au/latin-culture

Peopleartpeople, http://www.peopleartpeople.com/education.html

Spanishaustralia, http://www.spanishaustralia.org/arts

Viva Magazine, http://www.vivamagazine.com.au/ 
This text taken from Australia and Latin America: Challenges and Opportunities in the New Millennium, Edited by Barry Carr \& John Minns, published 2014 by ANU Press, The Australian National University, Canberra, Australia. 